\title{
Optimization of the re-extraction process of ethanol from catechin components from Korean green tea extract
}

\author{
In-Hee Jo ${ }^{1}$, Myung-Kyoo Kim ${ }^{1}$, Suh-Yoon Jang ${ }^{1}$, Na-Ra Kim ${ }^{1}$, Won-Young Lee ${ }^{2 *}$ \\ ${ }^{1}$ Research and Development Center, SAMKYUNG COSTECH Co., Ltd., Suwon 16681, Korea \\ ${ }^{2}$ Department of Food Science and Technology, Kyungpook National University Daegu 41566, Korea
}

\section{한국산 녹차추출물 catechin 성분의 ethanol 재추출 공정 최적화}

\author{
조인희 ${ }^{1} \cdot$ 김명 규 $^{1} \cdot$ 장서윤 $^{1} \cdot$ 김나라 $^{1} \cdot$ 이원 영 ${ }^{2 *}$ \\ ${ }^{1}$ (주)삼경코스텍 연구개발, ${ }^{2}$ 경북대학교 식품공학부
}

\begin{abstract}
The purpose of this study was to determine the optimum re-extraction conditions of ethanol from catechin in Korean green tea (Camellia sinensis L.) using response surface methodology (RSM). The experiments were carried out according to a five level and two variable central composite design (CCD). The two independent variables were solvent ratio to sample content $(1,4,7,10,13 \mathrm{~mL} / \mathrm{g})$ and extraction temperature $\left(-20,-10,0,10,20^{\circ} \mathrm{C}\right)$ on the dependent variables including yield, epigallocatechin (EGC), epicathchin (EC), epigallocatechingallate (EGCG), epicatechingallate (ECG), total catechin and caffeine. ANOVA results showed that Coefficients of determination $\left(R^{2}\right)$ of estimated models for dependent variables were ranged from $0.9054-0.9778$, while $R^{2}$ of caffeine were estimated 0.8770. The optimum ranges for the maximized extraction including yield, EGC, EC, EGCG, ECG, caffeine and total catechin were $4.5 \sim 7.5 \mathrm{~mL} / \mathrm{g}$ in ratio of ethanol to sample and $-8 \sim 8^{\circ} \mathrm{C}$ in extraction temperature. The actual values of yield, EGC, EC, EGCG, ECG, caffeine and total catechin, respectively, at the optimized conditions were $35.02 \%, 13.31 \%, 3.978 \%, 19.11 \%, 4.29 \%, 5.30 \%$ and $40.68 \%$
\end{abstract}

Key words : green tea, Camella sinensis L., optimization, response surface methodology, catechin

\section{서 론}

녹차는 차나무(Camella sinensis L.)에서 어린잎을 채취하 여 가공한 것으로 전 세계적으로 많이 음용되고 있는 기호 식품중의 하나로 다양한 생리활성 효과도 있는 것으로 알려 져 있다(1). 녹차의 성분은 채엽 시기(2), 품종(3), 재배환경 (4) 등에 따라 차이가 난다고 알려져 있으며 특히 녹차에 함유되어있는 카테킨 화합물의 양이나 질은 $\mathrm{pH}$, 온도, 효소 처리 등의 추출조건이나 방법에 따라서 크게 좌우된다고 보고되고 있다(5). 차는 당, 유기산, 질소화합물, polyphenol,

*Corresponding author. E-mail : wonyoung@knu.ac.kr Phone : 82-53-950-7763, Fax : 82-53-950-7762

Received 2 June 2016; Revised 5 July 2016; Accepted 20 July 2016.

Copyright (c) The Korean Society of Food Preservation. All rights reserved.
섬유질, 비타민 및 무기질로 구성되어 있고 이들 중 polyphenol류를 상당량 함유하고 있다(6). 차에 함유된 주요 polyphenol류는 flavonoid와 이의 유도체인데 카테킨 화합 물은 flavonoid 유도체의 단량체인 flavan 3-ol을 칭한다(7). 녹차의 주요 카테킨 화합물은 (-)-Epicatechin(EC), (-)Epigallocatechin(EGC), (-)-Epicatechingallate(ECG), (-)Epigallocatechingallate(EGCG) 등이다(8). 이러한 녹차의 카테킨 화합물은 항산화 작용, 항균작용, 항암작용, 콜레스 테롤 저하 등의 작용과 카페인에 의한 중추신경 흥분, 이뇨, 강심, 수렴, 해열 등의 작용이 있는 것으로 보고되고 있다 (9-14). 우리나라 음료 시장은 소득수준이 향상되면서 2000 년대 이후 건강 지향적인 관심도의 증가, 문화상품으로서 의 인식 등으로 웰빙 식품에 대한 소비가 확대되고 있으며 특히, 20,30 대 여성들을 중심으로 건강뿐만 아니라 미용에 대한 관심도 동시에 높아지고 있는 실정이다. 특히 2008년 3 월 건강기능성식품에 관한 정의를 법률로 개정, 공포하여 
건강기능성식품을 손쉽게 접할 수 있게 되었고 녹차와 오가 피차 등 다이어트 및 기타 기능성을 강조한 식물소재를 이용한 대용차 및 건강기능성 식품이 급성장하고 있는 추세 이다(15). 이러한 녹차의 추출물을 보다 고순도로 이용하고 자 녹차로부터 카테킨을 정제하기 위해 크로마토그래피법 및 활성탄과 같은 흡착제를 이용하여 녹차추출물로부터 카테킨 성분을 분배 추출 및 분리하는 연구가 보고되어있다 (16). 그러나 이와 같은 방법은 추출 및 정제과정이 복잡하 고 시간이 많이 걸리거나 가격이 비싸다는 단점을 가지고 있어서 경제적이면서도 비교적 단순한 공정의 카테킨 성분 을 추출하고 분리, 정제하는 공정의 개발이 요구되고 있다. 한편 chloroform과 ethyl acetate등과 같은 유기용매를 이용 하여 고순도로 카테킨을 정제하는 것에 대하여 보고(17)된 연구에 의하면 녹차 추출물을 유기용매로 정제시 녹차 건고 물기준 함량이 46 47\%로 증가하여 고순도 녹차 추출물의 제조에 효과적이라고 보고되었다. 그러나 chloroform과 ethyl acetate등의 유기용매는 대용량 단위의 식품제조에 사용하기에는 건강 및 공정상 위험요소가 많을 뿐 아니라 생산비용도 증가할 것으로 사료되어 본 연구에서는 chloroform과 ethyl acetate의 용매를 이용한 방법을 참고하 여 식품으로서 안전하고 비교적 생산비용을 절감할 수 있는 방안으로 에탄올만 이용하여 식품가공 및 건강기능성 식품 산업에 효과적으로 적용하고자 하였다. 본 연구에서는 녹 차 추출물의 유용성분인 카테킨화합물과 카페인을 발효주 정을 이용하여 식품으로서의 안전성 확보와 더불어 비교적 단순한 공정으로 카테킨 성분을 보다 고순도로 추출하고자 에탄올 용매비 및 추출온도에 따른 성분을 반응표면분석을 통하여 최적 조건을 탐색하였다.

\section{재료 및 방법}

\section{실험재료}

본 실험에서 사용된 녹차는 농업회사 법인 J사(Korea)에 서 2015년 10월에 제조된 녹차 분쇄 잎을 제공받아 사용하 였다. 녹차 성분 분석을 위한 표준품 (-)-Epicatechin(EC), (-)-Epigallocatechin(EGC), (-)-Epicatechingallate(ECG), (-)Epigallocatechingallate(EGCG) 및 카페인은 Sigma Chemical Co.(St. Louis, MO, USA) 제품을 사용하였고 Acetonitrile, Water 등 용매는 HPLC용으로 Burdick\&Jackson(Morris Plains, NJ, USA)제품을 사용하였다. 추출용 에탄올은 $95 \%$ 식음용 발효주정(Ethanol Supplies World Co., Ltd., Jeonju, Korea)을 사용하였다.

\section{녹차 추출물 제조 및 재추출조건의 예비설정}

본 연구에서 에탄올 재추출 조건의 예비 설정에 필요한 녹차의 추출 방법은 $\operatorname{Kim}(17)$ 의 방법을 참고하였으며 추출, 여과 및 농축 등 설비와 최종 제품 제조에 투입되는 생산비
용 등의 경제성을 고려하여 적용 가능한 전처리 추출 조건 을 설정하였다. 즉 Fig. 1에 나타낸 바와 같이 녹차 100 $\mathrm{g}$ 에 $50 \%$ 에탄올을 $1,500 \mathrm{~g}$ 을 가한 후 $70^{\circ} \mathrm{C}$ 에서 3 시간동안 추출한 액을 Whatman filter paper(Filter number 2, GE Healthcare, Buckinghamshire, UK) 여과 후 회전농축기 (EYELA N-1000, Sunileyera, Seongnam, Korea)로 감압건조 한 건고물을 시료로 사용하였다. 이 녹차 추출 건고물 5 $\mathrm{g}$ 에 $50,95,99 \%$ 에탄올 농도, 시료대 용매비를 $3,10,20$ $\mathrm{mL} / \mathrm{g}$ 및 온도 $-5,20^{\circ} \mathrm{C}$ 에서 재추출하여 여과된 재추출물을 HPLC 분석을 통해 추출조건 최적화 실험의 기본조건으로 활용하였다.

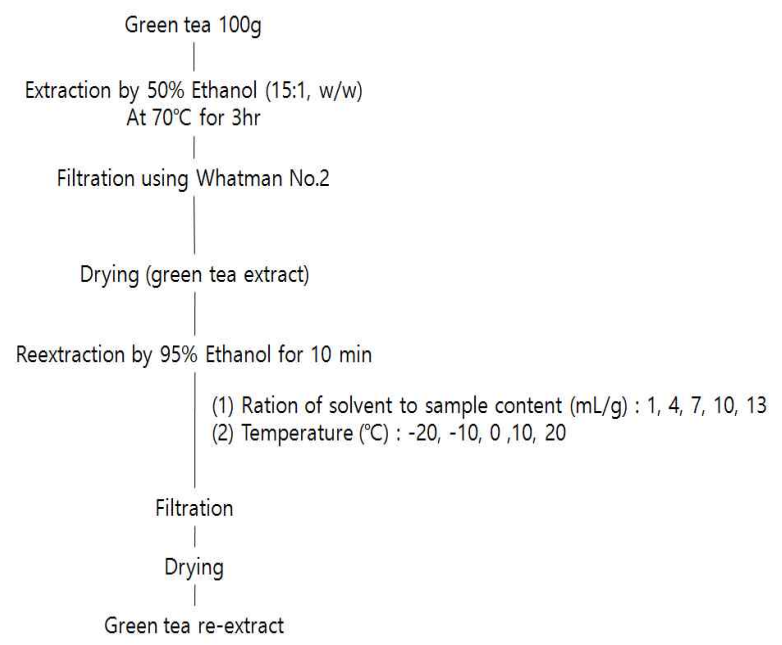

Fig. 1. Scheme for extraction and re-extraction of catechin and caffeine from green tea.

에탄올 재추출 조건 최적화를 위한 중심합성 실험 계획

에탄올을 이용한 녹차의 카테킨 성분의 최적 재추출 조 건을 알아내기 위해 반응표면분석법(response surface methodology, RSM)을 사용하였으며 예비실험의 결과를 바 탕으로 중심합성계획(central composite design)을 실시하였 다. 에탄올 재추출 공정의 독립변수 $(\mathrm{Xn})$ 는 에탄올 용매비 $(\mathrm{mL} / \mathrm{g})\left(\mathrm{X}_{1}\right)$ 와 추출 온도 $\left({ }^{\circ} \mathrm{C}\right)\left(\mathrm{X}_{2}\right)$ 에 대한 실험 범위를 선정하 여 5 단계 $(-2,-1,0,1,2)$ 로 나누어 Table 1에 나타내었고 중심합성계획에 따른 실험구는 Table 2에 나타내었다. 이들 독립변수에 의해 영향을 받는 종속 변수( $\mathrm{Yn})$ 는 건고물 수율 $\left(\mathrm{Y}_{1}\right)$ 과 건강기능식품의 기준 및 규격(18)에 고시된 녹차 추출물의 규격에 근거하여 카테킨류 즉, $\mathrm{EGC}\left(\mathrm{Y}_{2}\right), \mathrm{EC}\left(\mathrm{Y}_{3}\right)$, $\operatorname{EGCG}\left(\mathrm{Y}_{4}\right), \operatorname{ECG}\left(\mathrm{Y}_{5}\right)$ 함량과 카페인 함량 $\left(\mathrm{Y}_{6}\right)$ 으로 설정하 였으며 3회 반복 측정한 후 각각 회귀분석을 실시하였다. 반응표면분석은 SAS software(Version 9.2, SAS institute Inc., Cary, NC, USA)를 이용하여 회귀분석에 의한 최적조 건을 예측하였으며 회귀분석 결과 임계점이 최대점 혹은 최소점이 아니고 안장점일 경우에는 능선분석을 통하여 최적점을 구하였으며, 본 실험에 사용된 회귀식은 다음과 
같다.

$$
\mathrm{Y}=\mathrm{b}_{0}+\mathrm{b}_{1} \mathrm{X}_{1}+\mathrm{b}_{2} \mathrm{X}_{2}+\mathrm{b}_{11} \mathrm{X}_{1}^{2}+\mathrm{b}_{12} \mathrm{X}_{1} \mathrm{X}_{2}+\mathrm{b}_{22} \mathrm{X}_{2}^{2}
$$

추출특성의 모니터링과 예측된 모델식을 이용하여 3 차 원 반응표면분석으로 최적 조건 범위를 해석하였다.

Table 1. Independent variables and their coded and actual values used for analysis

\begin{tabular}{ccccccc}
\hline \multirow{2}{*}{ Symbol } & \multirow{3}{*}{ Independent variable } & \multicolumn{5}{c}{ Coded level } \\
\cline { 3 - 7 } & & -2 & -1 & 0 & 1 & 2 \\
\hline $\mathrm{X}_{1}$ & Ratio of solvent to sample content $(\mathrm{mL} / \mathrm{g})$ & 1 & 4 & 7 & 10 & 13 \\
$\mathrm{X}_{2}$ & Extraction temperature $\left({ }^{\circ} \mathrm{C}\right)$ & -20 & -10 & 0 & 10 & 20 \\
\hline
\end{tabular}

Table 2. The central composite design for the optimization of leaching condition of Green Tea

\begin{tabular}{ccc}
\hline No. & Ratio of solvent to sample content $(\mathrm{mL} / \mathrm{g})$ & Extraction temperature $\left({ }^{\circ} \mathrm{C}\right)$ \\
\hline 1 & $7(0)$ & $20(2)$ \\
2 & $7(0)$ & $0(0)$ \\
3 & $7(0)$ & $0(0)$ \\
4 & $4(-1)$ & $10(1)$ \\
5 & $7(0)$ & $0(0)$ \\
6 & $7(0)$ & $-20(-2)$ \\
7 & $10(1)$ & $10(1)$ \\
8 & $13(2)$ & $0(0)$ \\
9 & $10(1)$ & $-10(-1)$ \\
10 & $1(-2)$ & $0(0)$ \\
11 & $4(-1)$ & $-10(-1)$ \\
12 & $7(0)$ & $0(0)$ \\
13 & $7(0)$ & $0(0)$ \\
\hline
\end{tabular}

\section{추출수율}

수율은 에탄올에 재추출된 액을 증류, 농축하여 얻은 건 고물의 무게를 측정하여 사용된 녹차 추출물 사용량의 백분 율(\%)로 나타내었다.

\section{카테킨 및 카페인 함량 분석}

카테킨류 및 카페인은 Choung과 Lee의 방법(19)을 변형 하여 분석하였다. 녹차의 카테킨 및 카페인 분석은 HPLC (Waters Co., Ltd, Miliford, MA, USA)를 이용하여 분석하였 고 분석 조건은 Table 3에 나타내었다. 에탄올 재추출 전 녹차 추출물의 카테킨 함량은 $30.91 \%$, 카페인 함량은 $4.5 \%$ 인 것을 시료로 사용하였다. 각 시험구의 분석결과는 표준 물질의 retention time과 비교하여 3 번 반복 측정하였고 표준 시료의 peak 면적에 의해 산출된 백분율(\%)함량 값을 기준 으로 평균과 표준편차로 나타내었다.
Table 3. Operating conditions of HPLC for determination of catechin and caffeine

\begin{tabular}{|c|c|c|c|}
\hline Items & \multicolumn{3}{|c|}{ Conditions } \\
\hline Instrument & \multicolumn{3}{|c|}{ Waters Co., USA, 2695} \\
\hline Column & \multicolumn{3}{|c|}{ waters, $\mathrm{C} 18,3.5 \mu \mathrm{m}(4.6 \times 150 \mathrm{~mm})$} \\
\hline \multirow{5}{*}{ Mobilie phase } & $\begin{array}{l}\text { Time } \\
(\min )\end{array}$ & $\begin{array}{c}\text { A (\%) } \\
(0.1 \% \text { Trifluoroacetic acid) }\end{array}$ & $\begin{array}{c}\mathrm{B}(\%) \\
\text { (Acetonitrile) }\end{array}$ \\
\hline & 0 & 95 & 5 \\
\hline & 1 & 95 & 5 \\
\hline & 20 & 71 & 29 \\
\hline & 21 & 71 & 29 \\
\hline Flow rate & \multicolumn{3}{|c|}{$1 \mathrm{~mL} / \mathrm{min}$} \\
\hline Detector & \multicolumn{3}{|c|}{ UV detector } \\
\hline Injection volume & \multicolumn{3}{|c|}{$20 \mu \mathrm{L}$} \\
\hline Wave length & \multicolumn{3}{|c|}{$280 \mathrm{~nm}$} \\
\hline
\end{tabular}

\section{통계분석}

반응표면 분석, ANOVA 및 Duncan's multiple range test 는 SAS software(Version 9.2, SAS institute Inc., Cary, NC, USA)를 이용하여 수행하였다.

\section{결과 및 고찰}

에탄올 재추출 조건에 따른 추출물의 품질 특성

에탄올 재추출조건의 최적화를 위한 예비 설정에 필요한 실험으로 재추출 농도와 시료대 용매비, 온도에 대한 추출 특성을 확인하였고 이 결과에 따른 예비 실험 조건을 바탕 으로 중심합성계획을 실시하였다(Fig. 2). 총 카테킨 함량은 에탄올 농도가 높아질수록 증가하는 경향을 보였는데 $50 \%$ 에탄올 재추출은 $31.2 \%$ 로 에탄올 재추출전 녹차추출물의 총 카테킨 함량 $30.91 \%$ 와 차이가 거의 없었고, $99 \%$ 에탄올 로 재추출시 총카테킨 함량은 $47.38 \%$ (건고물 기준)로 가장 높았고 $95 \%$ 에탄올의 경우 $40.62 \%$ 로 나타났다. $99 \%$ 에탄 올의 경우 식품용으로 사용이 불가능하고 $95 \%$ 이하의 농도 에서는 재추출에 대한 효과가 미미하여 적용가능한 $95 \%$ 에탄올로 고정하여 실험을 진행하였다. 에탄올 사용 용매 비에 따른 총카테킨 함량은 시료대 용매비가 $3,10,20 \mathrm{~mL} / \mathrm{g}$ 으로 증가할수록 총카테킨 함량이 $41.21,36.79,34.43 \%$ 로 감소하였으며 카페인 함량도 유사한 경향을 나타내었다. 에탄올 재추출시 온도에 따른 총카테킨 함량은 $95 \%$ 에탄올 로 재추출시 온도가 낮을 때 카테킨 및 카페인 함량이 더 높음을 확인하였다. 추출시간에 대한 카테킨 및 카페인 함 량 변화는 거의 없어 효과가 없었다(data not shown). 따라서 에탄올 재추출 농도 $95 \%$, 재추출 시간은 10 분으로 고정하 고 시료대 용매비와 재추출 온도를 독립변수로 하여 중심합 성계획법에 의해 추출조건 최적화를 실시하였다. 


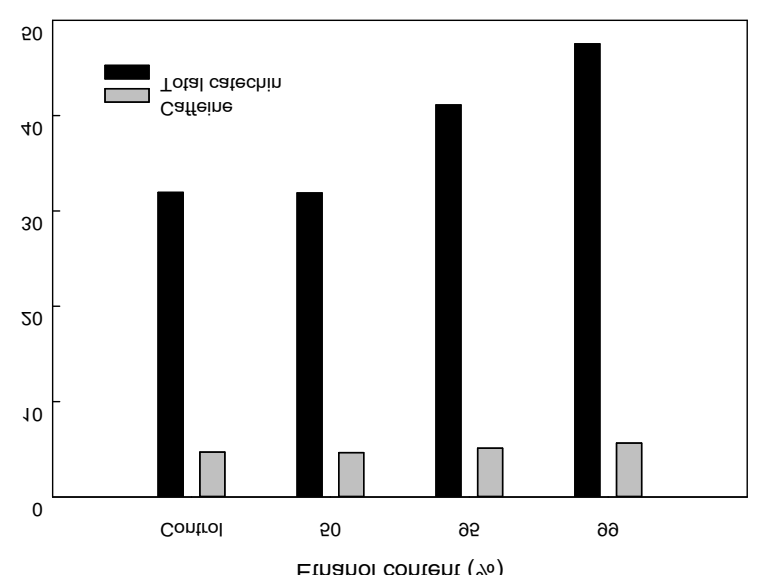

용매비가 증가함에 따라 수율도 증가하였고 용매비는 9 12 $\mathrm{mL} / \mathrm{g}$ 에서 최대값을 나타내었다. 반응표면 분석 결과 일차 적, 이차적 영향 모두 $99.9 \%$ 의 신뢰 수준 이상으로 유의하 였고 전체 회귀모델의 $\mathrm{R}^{2}$ 값이 0.9808 로 $\mathrm{p}<0.001$ 수준에서 유의성이 인정되었다(Table 5). 에탄올 사용 비율 이차항의 계수는 곡선형태로 $\mathrm{p}<0.001$ 으로 유의성이 인정되었으며, 음의 값으로 본 실험의 에탄올 용매비 범위 내에서 증가하 다 감소하는 형태를 보였다(Fig. 3, Table 5). 예측된 정상점 은 안장점으로 시료에 대한 에탄올 용매비 $9.38 \mathrm{~mL} / \mathrm{g}$, 추출 온도 $28.04^{\circ} \mathrm{C}$ 일 때 최대값 $55.15 \%$ 로 예측되었다.
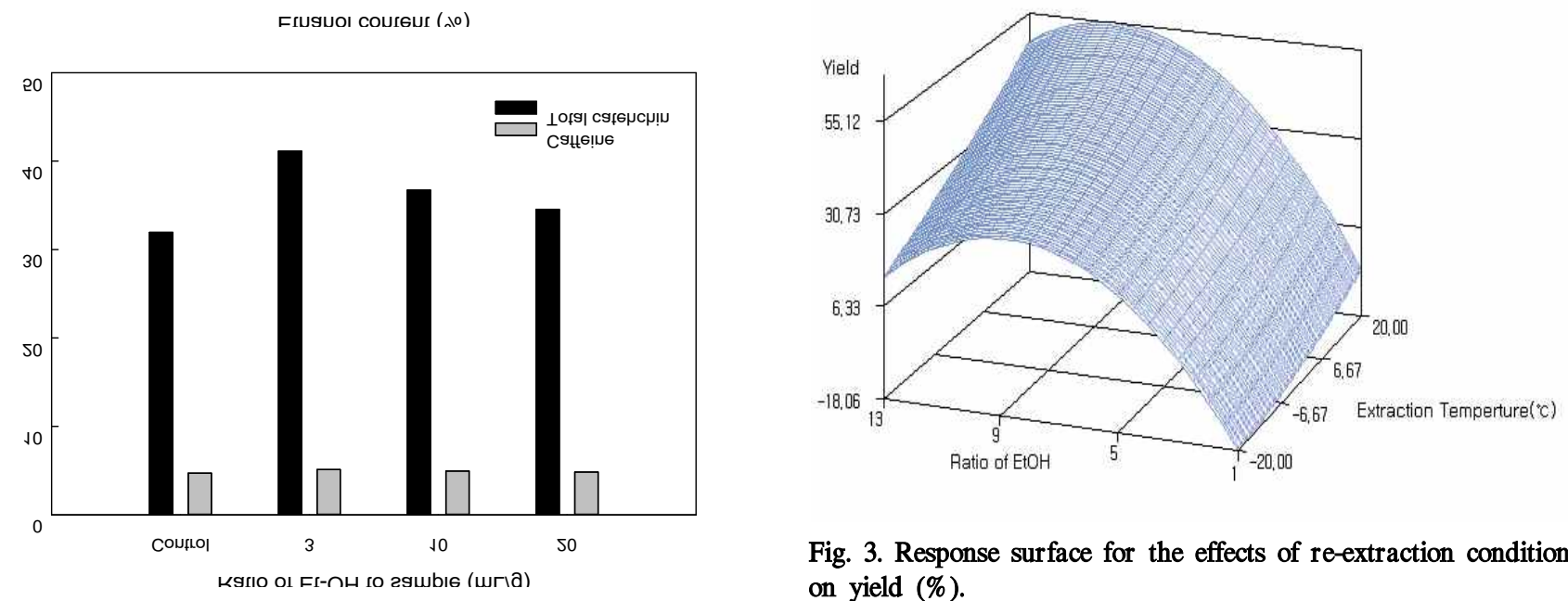

Fig. 3. Response surface for the effects of re-extraction condition on yield $(\%)$.

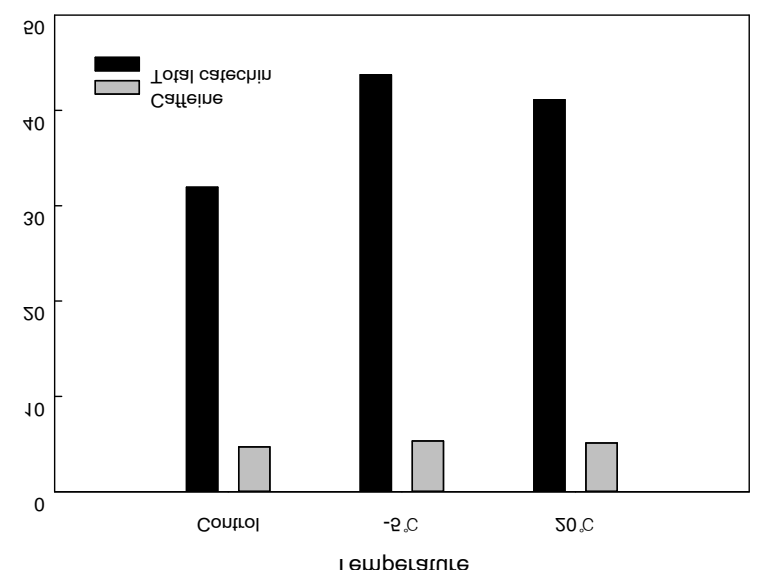

Fig. 2. Total catechin and caffeine content of green tea re-extracts by re-extract conditions.

\section{재추출 조건이 고형분 수율에 미치는 영향}

각 추출조건에 따른 녹차추출물의 수율은 에탄올 용매비 가 $1 \mathrm{~mL} / \mathrm{g}$, 온도 $0^{\circ} \mathrm{C}$ 일 때 고형분 수율은 $8.94 \%$ 로 가장 낮았고 에탄올 용매비가 $7 \mathrm{~mL} / \mathrm{g}$, 온도 $20^{\circ} \mathrm{C}$ 일 때 고형분 수율은 $51.91 \%$ 로 가장 높게 나타났다(Table 4). 반응표면 분석을 한 결과는 Fig. 3 에 나타낸 바와 같고 에탄올 용매비 와 추출 온도에 유의적이었다 $(\mathrm{p}<0.001)$. 추출온도의 경우

재추출 조건이 카테킨류 및 총 카테킨 함량에 미치는 영향

녹차의 높은 항산화 능력은 차의 성분 중 $10 ~ 30 \%$ 를 차지 하고 있는 카테킨들이 대표적인 생리활성 물질로 알려져 있으며 항산화력은 $\mathrm{EGC}>\mathrm{EGCG}>\mathrm{ECG}>\mathrm{EC}$ 순으로 나타난 다고 보고되었다(20). 그 중 $\mathrm{EGCG}$ 는 녹차카테킨 성분 중 가장 많은 양을 차지하고 있고 가장 강력한 항암 작용을 한다고 보고된 바 있다(21). 이에 본 실험에서 독립변수 조건에 의한 각 성분 함량의 영향을 알아보고자 녹차 카테 킨의 $\mathrm{EGC}, \mathrm{EC}, \mathrm{EGCG}, \mathrm{ECG}$ 의 함량과 성분의 합하여 나타 낸 총 카테킨 함량의 반응표면분석을 수행하였다. 중심합 성계획법에 따른 추출조건별 녹차추출물의 에탄올 재추출 결과 총 카테킨 함량은 에탄올 재추출 전 $32 \%$ 에서 에탄올 재추출 후 카테킨 함량이 약 41 46\%까지 올라갔으며 에탄 올 재추출전과 재추출후의 카테킨 함량의 HPLC 분석 결과 를 Fig. 4에 나타내었다. 동일한 농도에서 HPLC 분석시 재추출 후의 카테킨 함량의 peak도 증가한 것을 확인할 수 있었다. 녹차의 에탄올 재추출에 대한 카테킨 성분 및 총카테킨 함량의 반응표면 분석결과는 Fig. 5 에 나타내었으 며 카테킨의 각각 성분은 총카테킨 함량의 반응표면 분석결 과와 유사하여 하나의 그림으로 나타내었다. 시료대 용매 비는 추출온도가 낮을때는 함량 변화가 적었으나 추출온도 
Table 4. Experimental data on dependent variables of green tea re-extract under the different conditions based on the central composite design for response surface analysis

\begin{tabular}{|c|c|c|c|c|c|c|c|}
\hline $\begin{array}{l}\text { Ext }_{\text {i) }} \\
\text { No. }\end{array}$ & Yield (\%) & $\mathrm{EGC}^{2)}(\%)$ & $\mathrm{EC}(\%)$ & ECGC (\%) & ECG $(\%)$ & Caffeine (\%) & Total catechin (\%) \\
\hline 1 & $51.91 \pm 0.38^{\mathrm{a} 3)}$ & $11.8 \pm 0.22^{\mathrm{bc}}$ & $3.5 \pm 0.04^{\text {bcd }}$ & $21.74 \pm 0.21^{\mathrm{bc}}$ & $5.25 \pm 0.04^{b}$ & $5.91 \pm 0.02^{\mathrm{cd}}$ & $42.29 \pm 0.47^{b}$ \\
\hline 2 & $35.77 \pm 0.07^{\mathrm{d}}$ & $12.49 \pm 0.51^{\text {de }}$ & $3.77 \pm 0.14^{\mathrm{defg}}$ & $22.44 \pm 0.71^{d}$ & $5.26 \pm 0.13^{\mathrm{cd}}$ & $5.84 \pm 0.02^{\mathrm{de}}$ & $43.96 \pm 1.41^{\text {cd }}$ \\
\hline 3 & $36.21 \pm 0.46^{\mathrm{d}}$ & $12.72 \pm 0.21^{\mathrm{abc}}$ & $3.64 \pm 0.05^{\text {defg }}$ & $21.95 \pm 0.15^{\mathrm{bcd}}$ & $5.33 \pm 0.08^{\mathrm{bc}}$ & $5.87 \pm 0.08^{b c d}$ & $43.63 \pm 0.29^{b c}$ \\
\hline 4 & $26.79 \pm 1.09^{f}$ & $13.05 \pm 0.04^{\mathrm{ab}}$ & $3.87 \pm 0.09^{\mathrm{abc}}$ & $23.64 \pm 0.16^{b}$ & $5.68 \pm 0.08^{\mathrm{bc}}$ & $6.24 \pm 0.09^{\text {cde }}$ & $46.23 \pm 0.19^{b}$ \\
\hline 5 & $38.8 \pm 0.91^{\mathrm{c}}$ & $12.45 \pm 0.07^{\mathrm{bcd}}$ & $3.77 \pm 0.03^{\text {cdef }}$ & $22.4 \pm 0.45^{\mathrm{bed}}$ & $5.29 \pm 0.05^{\mathrm{b}}$ & $5.88 \pm 0.08^{\mathrm{bc}}$ & $43.9 \pm 0.40^{\mathrm{bc}}$ \\
\hline 6 & $25.3 \pm 0.85^{\mathrm{f}}$ & $11.71 \pm 0.21^{\text {de }}$ & $3.56 \pm 0.03^{\text {efgh }}$ & $20.8 \pm 0.26^{\mathrm{d}}$ & $4.95 \pm 0.19^{\mathrm{cd}}$ & $5.68 \pm 0.06^{\mathrm{cde}}$ & $41.02 \pm 0.65^{\mathrm{cd}}$ \\
\hline 7 & $42.12 \pm 0.72^{b}$ & $11.79 \pm 0.21^{\mathrm{a}}$ & $3.53 \pm 0.04^{\mathrm{a}}$ & $21.47 \pm 0.81^{\mathrm{a}}$ & $4.99 \pm 0.15^{\mathrm{a}}$ & $5.82 \pm 0.22^{\mathrm{b}}$ & $41.78 \pm 1.16^{\mathrm{a}}$ \\
\hline 8 & $30.68 \pm 2.07^{\mathrm{e}}$ & $11.69 \pm 0.09^{f}$ & $3.44 \pm 0.08^{\mathrm{i}}$ & $20.77 \pm 0.29^{\mathrm{e}}$ & $5.01 \pm 0.07^{\mathrm{de}}$ & $5.76 \pm 0.09^{\mathrm{de}}$ & $40.92 \pm 0.52^{\mathrm{e}}$ \\
\hline 9 & $30.9 \pm 1.29^{\mathrm{e}}$ & $12.18 \pm 0.44^{\text {ef }}$ & $3.62 \pm 0.1^{\mathrm{hi}}$ & $21.54 \pm 0.38^{\text {ed }}$ & $5.2 \pm 0.12^{\mathrm{c}}$ & $5.79 \pm 0.06^{\mathrm{bcd}}$ & $42.54 \pm 0.86^{\mathrm{d}}$ \\
\hline 10 & $8.94 \pm 1.00^{\mathrm{h}}$ & $13.03 \pm 0.17^{\mathrm{a}}$ & $3.94 \pm 0.07^{\mathrm{ab}}$ & $23.33 \pm 0.19^{\mathrm{a}}$ & $5.75 \pm 0.12^{\mathrm{a}}$ & $6.02 \pm 0.02^{\mathrm{a}}$ & $46.06 \pm 0.51^{\mathrm{a}}$ \\
\hline 11 & $21.29 \pm 1.01^{g}$ & $12.16 \pm 0.36^{\mathrm{cd}}$ & $3.65 \pm 0.09^{\text {cde }}$ & $21.62 \pm 0.42^{\mathrm{bc}}$ & $5.18 \pm 0.17^{\mathrm{c}}$ & $5.76 \pm 0.03^{\mathrm{bcd}}$ & $42.61 \pm 0.92^{\mathrm{bc}}$ \\
\hline 12 & $36.46 \pm 0.30^{d}$ & $12.61 \pm 0.17^{\mathrm{f}}$ & $3.79 \pm 0.04^{\mathrm{fghi}}$ & $22.4 \pm 0.16^{\mathrm{e}}$ & $5.38 \pm 0.13^{\mathrm{e}}$ & $5.82 \pm 0.05^{\mathrm{e}}$ & $44.18 \pm 0.36^{\mathrm{e}}$ \\
\hline 13 & $35.33 \pm 0.44^{d}$ & $12.37 \pm 0.13^{\mathrm{ef}}$ & $3.71 \pm 0.08^{\text {ghi }}$ & $22.04 \pm 0.20^{\mathrm{d}}$ & $5.48 \pm 0.03^{\mathrm{e}}$ & $5.91 \pm 0.10^{\text {cde }}$ & $43.6 \pm 0.42^{\mathrm{de}}$ \\
\hline
\end{tabular}

The number of experimental condition by central composite design

${ }^{2)}$ Epigallocatechin (EGC), Epicathchin (EC), Epigallocatechingallate (EGCG), Epicatechingallate (ECG)

${ }^{3)}$ Mean of triplicates $\pm S D(n=3)$. Values sharing the same superscript within are not significantly different $(a=0.05)$.

Table 5. Estimated coefficients of second order response models for green tea

\begin{tabular}{cccccccc}
\hline & Yield $(\%)$ & EGC $^{2}(\%)$ & EC $(\%)$ & ECGC $(\%)$ & ECG $(\%)$ & Caffeine $(\%)$ & Total catechin $(\%)$ \\
\hline Intercept & $-0.48^{* * * 3)}$ & $13.07^{* * *}$ & $3.94^{* * *}$ & $23.45^{* * *}$ & $5.8^{* * *}$ & $6.09^{* * *}$ & $42.26^{* * *}$ \\
$\mathrm{X}_{1}{ }^{1)}$ & $8.47^{* * *}$ & $-0.05^{* * *}$ & $-0.02^{* * *}$ & $-0.13^{* * *}$ & $-0.07^{* * *}$ & $-0.04^{* *}$ & $-0.27^{* * *}$ \\
$\mathrm{X}_{2}$ & $0.25^{* * *}$ & 0.08 & 0.02 & $0.15^{* *}$ & $0.049^{* *}$ & 0.03 & $0.3^{* *}$ \\
$\mathrm{X}_{1} \mathrm{X}_{1}$ & $-0.47^{* * *}$ & -0.005 & -0.001 & $-0.005^{*}$ & 0.0009 & 0.0008 & -0.01 \\
$\mathrm{X}_{1} \mathrm{X}_{2}$ & 0.005 & $-0.002^{* * *}$ & $-0.0005^{* *}$ & $-0.002^{* *}$ & $-0.0006^{* *}$ & $-0.0002^{*}$ & $-0.005^{* * *}$ \\
$\mathrm{X}_{2} \mathrm{X}_{2}$ & 0.05 & $-0.01^{* *}$ & $-0.0025^{*}$ & $-0.02^{* *}$ & $-0.006^{* *}$ & $-0.004^{*}$ & $-0.04^{* * *}$ \\
$\mathrm{R}^{2}$ & $0.9670^{* * *}$ & $0.9621^{* * *}$ & $0.9054^{* * *}$ & $0.9496^{* * *}$ & $0.9550^{* * *}$ & $0.8770^{* *}$ & $0.9778^{* * *}$ \\
\hline
\end{tabular}

$\mathrm{Y}=\mathrm{b}_{0}+\mathrm{b}_{1} \mathrm{X}_{1}+\mathrm{b}_{2} \mathrm{X}_{2}+\mathrm{b}_{11} \mathrm{X}_{1}^{2}+\mathrm{b}_{12} \mathrm{X}_{1} \mathrm{X}_{2}+\mathrm{b}_{22} \mathrm{X}_{2}$

${ }^{1)} X_{1}$, ratio of solvent to sample content $(\mathrm{mL} / \mathrm{g}) ; \mathrm{X}_{2}$, Extraction temperature $\left({ }^{\circ} \mathrm{C}\right)$.

${ }^{2)}$ Epigallocatechin (EGC), Epicathchin (EC), Epigallocatechingallate (EGCG), Epicatechingallate (ECG).

${ }^{3) *}$ Significant at $0.1 \%$ level; ${ }^{* *}$ Significant at $0.05 \%$ level; ${ }^{* * *}$ Significant at $0.01 \%$ level.

가 높을 때는 함량 변화가 유의적이었다. 추출온도가 일정 할 때 에탄올 용매비가 적어질 수 록 카테킨 함량이 증가하 는 경향성을 보였다. 또한 에탄올 재추출 온도가 낮아질수 록 카테킨 함량이 증가하는 경향성을 나타내었다. Pinelo 등(22)의 보고에 의하면 polyphenol은 에탄올에서 추출이 잘되고 온도와 용매비가 증가할수록 total polyphenol 함량 은 증가한다고 보고되었는데 본 실험에서는 추출물을 에탄 올로 재추출했을 때는 오히려 온도가 낮아질수록 카테킨 함량이 더 높게 나타나 Pinelo 등(22)의 보고와 다른 결과를 나타내었다. 그리고 polyphenol의 하나인 (+)-카테킨은 온 도와 에탄올 농도가 증가할수록 용해도가 증가하는데 이와 같은 결과는 대기압상태의 물/에탄올 혼합물에서는 극성정
도가 온도에 영향을 받고 온도가 낮아질수록 극성정도는 작아지고, 에탄올 농도는 증가할수록 극성정도가 작아져 용해도가 증가한다고 보고되었다(23,24). 한편, Lourdes 등 (25)의 의하면 D-glucose는 에탄올/물 혼합물에서 에탄올 농도가 낮아질수록 용해도가 증가하며 특히 물에서 용해도 가 가장 높고 온도가 높을수록 용해도가 증가한다고 보고되 었고, 아미노산도 에탄올에 비해 극성이 큰 물에서 용해도 가 높다고 보고된 바 있다(26). 다시 말해, 본 실험에서 $95 \%$ 에탄올로 재추출시 온도에 따른 함량 결과는 $0^{\circ} \mathrm{C}$ 이하에서 상대적 극성정도에 따른 에탄올의 용해 영향력 증가, 물 가용성분의 용해도 감소의 2 가지 요인이 상호보완적으로 작용한 것으로 판단된다. $\mathrm{EGC,} \mathrm{EGCG}$ 와 총 카테킨 함량은 


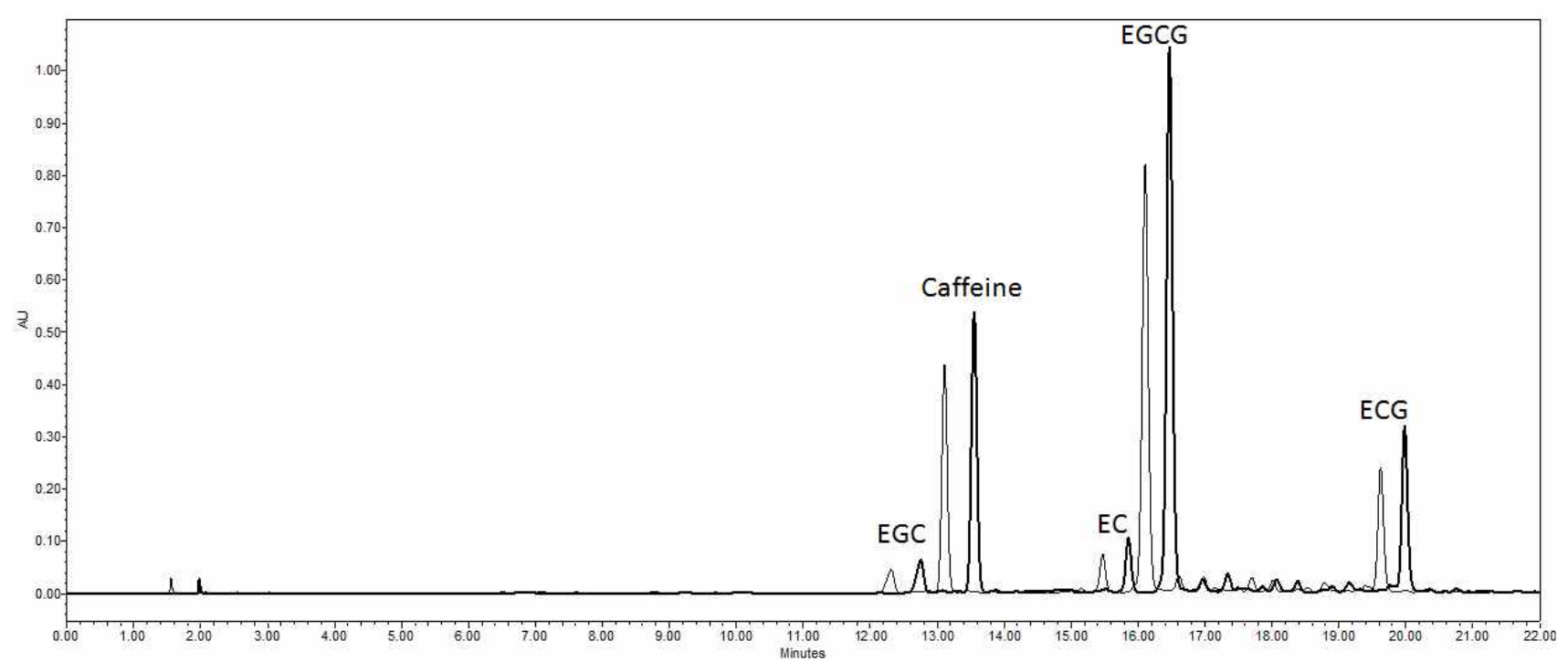

Fig. 4. HPLC profiels for catechin and caffeine of green tea extract and green tea ethanol re-extract (Thick line).

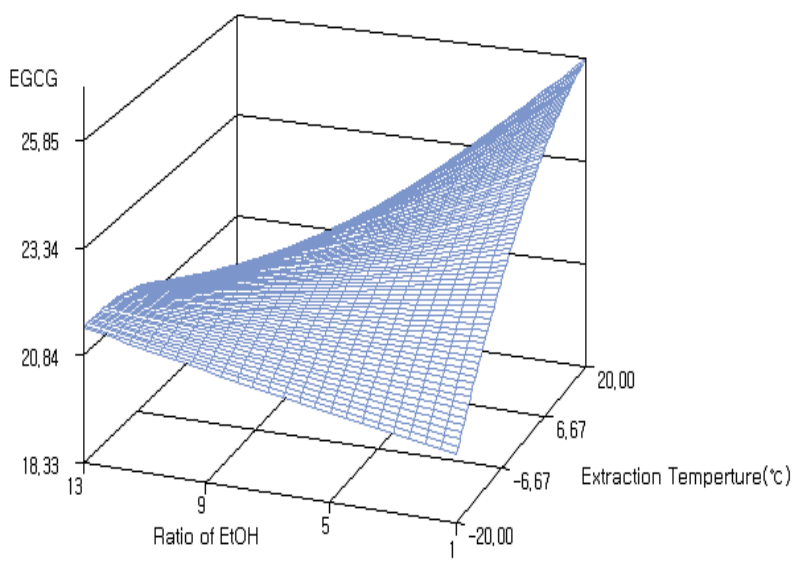

Fig. 5. Response surface for the effects of re-extraction condition on EGC, EC, EGCG, ECG and total catechin content (\%).

에탄올 용매비 $4 \mathrm{~mL} / \mathrm{g}$ 에서 온도 $10^{\circ} \mathrm{C}$ 일 때, $\mathrm{EC}$ 와 $\mathrm{ECG}$ 는 에탄올 용매비 $1 \mathrm{~mL} / \mathrm{g}$ 에 온도 $0^{\circ} \mathrm{C}$ 일 때 가장 높은 값을 나타내었다(Table 6). 녹차의 카테킨류와 총 카테킨의 분석 결과는 Table 4 에 나타내었으며 $\mathrm{R}^{2}$ 값은 0.90 이상이었고 $1 \%$ 이내의 유의성이 인정되었다(Table 5). 특히, 총카테킨 함량 의 R2는 0.9778 로 가장 높은 수준의 유의성이 인정되었다. $\mathrm{EGC}, \mathrm{EC}, \mathrm{EGCG}, \mathrm{ECG}$ 및 총 카테킨 함량의 분산분석 결과 일차, 이차 및 상호작용도 유의적으로 나타났다. 녹차 추출 물의 에탄올 재추출에서 $\mathrm{EGC}$ 는 용매비 $1.60 \mathrm{~mL} / \mathrm{g}$, 온도 $16.52^{\circ} \mathrm{C}$ 에서 최대 함량 $13.82 \%$ 로, $\mathrm{EC}$ 는 용매비 $1.45 \mathrm{~mL} / \mathrm{g}$, 온도 $15.14^{\circ} \mathrm{C}$ 에서 최대 함량 $4.08 \%, \mathrm{EGCG}$ 는 용매비 1.75 $\mathrm{mL} / \mathrm{g}$, 온도 $17.69^{\circ} \mathrm{C}$ 에서 최대 함량 $24.98 \%, \mathrm{ECG}$ 는 용매비 $1.77 \mathrm{~mL} / \mathrm{g}$, 온도 $17.81^{\circ} \mathrm{C}$ 에서 최대 함량 $6.26 \%$ 로 예측되었다. 총 카테킨 최대 함량은 $49.14 \%$ 로 예측되었으며, 이때의 추출 조건은 용매비 용매비 $1.68 \mathrm{~mL} / \mathrm{g}$, 온도 $17.19^{\circ} \mathrm{C}$ 로 나타났다.
Table 6. Predicted values of optimum condition for the maximized and minimized responses to variables by the ridge analysis by their response surface

\begin{tabular}{ccccc}
\hline & $\mathrm{X}_{1}{ }^{1)}$ & $\mathrm{X}_{2}$ & Estimated Responses & Morphology \\
\hline Yield (\%) & 9.38 & 28.04 & 55.15 (Max.) & saddle \\
EGC $^{2)}(\%)$ & 1.60 & 16.52 & $13.82($ Max.) & saddle \\
EC (\%) & 1.45 & 15.14 & $4.08($ Max.) & saddle \\
ECGC (\%) & 1.75 & 17.69 & 24.98 (Max.) & saddle \\
ECG (\%) & 1.77 & 17.81 & $6.26($ Max.) & saddle \\
Caffeine (\%) & 11.75 & 20.73 & 5.49 (Min.) & saddle \\
Total catechin (\%) & 1.68 & 17.19 & 49.14 (Max.) & saddle \\
\hline
\end{tabular}

${ }^{1)} \mathrm{X}_{1}$, ratio of solvent to sample content $(\mathrm{mL} / \mathrm{g}) ; \mathrm{X}_{2}$, Extraction temperature $\left({ }^{\circ} \mathrm{C}\right)$. ${ }^{2)}$ Epigallocatechin (EGC), Epicathchin (EC), Epigallocatechingallate (EGCG), Epicatechingallate (ECG).

재추출 조건이 총 카페인 함량에 미치는 영향

본 실험에서 카페인 함량은 에탄올 용매비 $4 \mathrm{~mL} / \mathrm{g}$ 에 온도 $10^{\circ} \mathrm{C}$ 일 때 카페인 함량 $6.24 \%$ 로 가장 높았고, 에탄올 용매 비 $11.75 \mathrm{~mL} / \mathrm{g}$, 온도 $20.73^{\circ} \mathrm{C}$ 에서 추출했을 때 카페인 함량 이 $5.49 \%$ 로 가장 낮았다(Table 6). 녹차추출물의 에탄올 재추출에 대한 카페인 함량은 Table 5에 나타낸 바와 같이 반응표면 분석 및 분산분석 결과 R2는 0.8770 로 $\mathrm{p}<0.01$ 의 유의성이 인정되었다. 일차 및 이차적 영향은 $\mathrm{p}<0.05$ 수준으 로 유의성이 인정되었고 에탄올 용매비 및 온도에 대한 상호작용도 유의적으로 나타났다(Table 3). 에탄올 재추출 에 대한 카페인함량의 반응표면 분석 결과는 Fig. 6에 나타 낸 바와 같으며 추출온도에 대한 카페인 함량은 용매비가 낮을때 온도가 증가할수록 카페인 함량이 증가하였고, 용 매비가 높을때 온도가 증가할수록 카페인 함량은 낮게 나타 났다. 


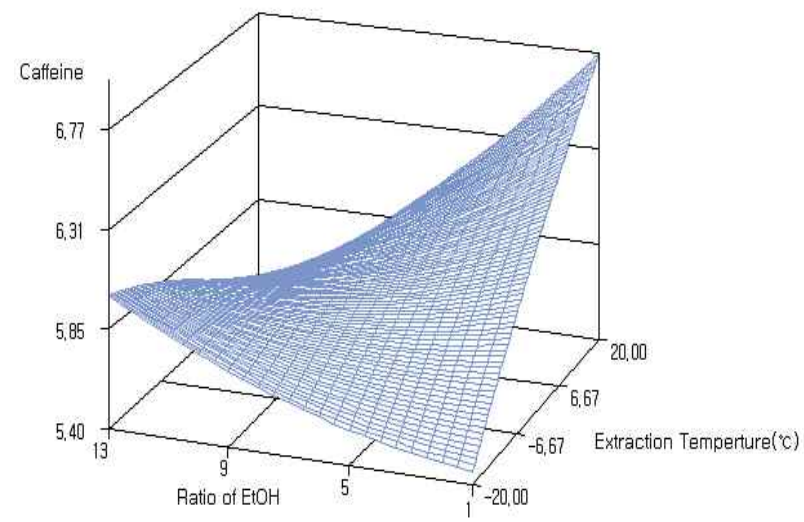

Fig. 6. Response surface for the effects of re-extraction condition on caffeine $(\%)$.

\section{최적 추출 조건 예측 및 실측}

녹차추출물의 카테킨 성분의 최적 추출조건 설정을 위해 추출조건에 따른 $\mathrm{EGC}, \mathrm{EC}, \mathrm{EGCG}, \mathrm{ECG}$, 총 카테킨 함량 및 카페인의 contour map을 superimposing하여 예측한 최적 추출조건은 에탄올 용매비 $6 \mathrm{~mL} / \mathrm{g}$ 에 $0^{\circ} \mathrm{C}$ 이며 Table 7 과 Fig. 7에 나타내었다. 예측값과 동일 조건에서 추출 실험을 한 결과 실제 실험 시 고형분 수율 $35.02 \% \mathrm{EGC} 13.31 \%$, EC 3.97\%, EGCG 19.11\%, ECG 4.29\%, 총 카테킨 함량 $40.68 \%$ 및 카페인은 $5.30 \%$ 을 나타내었다(Table 8). 에탄올

Table 7. Optimization of ethanol re-extraction condition for response variables by superimposing contour maps

\begin{tabular}{cc}
\hline Extraction conditions & Optimum ranges \\
\hline Ratio of solvent to sample content $(\mathrm{mL} / \mathrm{g})$ & $4.5 \sim 7.5$ \\
Extraction temperature $\left({ }^{\circ} \mathrm{C}\right)$ & $-8 \sim 8$ \\
\hline
\end{tabular}

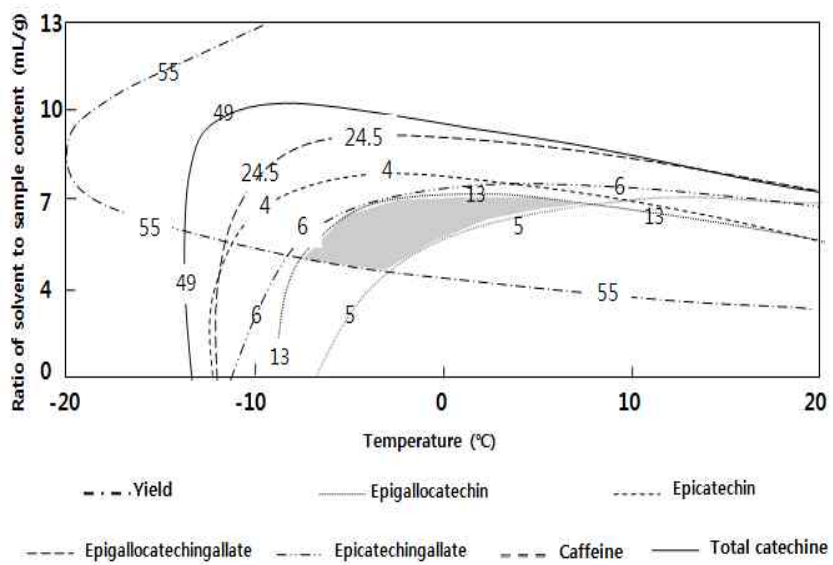

Fig. 7. Superimposing contour map of optimized conditions for the yield.

Yield, epigallocatechin (EGC), epicathchin (EC), epigallocatechingallate (EGCG), epicatechingallate $(\mathrm{ECG})$, caffeine and total catechin content of green tea.
추출 전 녹차 추출물 성분 함량에 대비 실측값의 녹차 추출 물 성분 함량 수율은 평균적으로 약 $44.42 \%$ 였다. Kwon 등(16)에 의하면 녹차 추출물의 카테킨 성분을 활성탄을 이용하여 추출하였는데 흡착제를 통한 추출시 카테킨 성분 손실이 있으며 공정상 고온에서 평균 흡착 시간이 6 8시간 에 걸쳐 함랑을 높일 수 있다고 보고되었는데 고온 및 장시 간 공정 조건을 고려하면 에탄올 추출에 의한 것이 비교적 단순한 공정으로 단시간 처리 가능하고 에탄올 가용성 부분 과 불용성 부분 모두를 활용 가능하다는 점에서 보다 고순 도의 카테킨 성분 추출을 효과적이고 경제적인 공정으로 활용될 수 있을 것이라고 사료된다.

Table 8. Predicted and experimental values of response variables for green tea at a given conditions within the range of optimum re-extraction conditions

\begin{tabular}{|c|c|c|c|c|c|}
\hline & \multicolumn{2}{|c|}{$\begin{array}{l}\text { Optimum } \\
\text { condition }\end{array}$} & \multirow{2}{*}{$\begin{array}{l}\text { Predicted } \\
\text { value }\end{array}$} & \multirow{2}{*}{ Actual value } & \multirow{2}{*}{$\begin{array}{l}\text { Error } \\
(\%)\end{array}$} \\
\hline & $\mathrm{X}_{1}$ & $\mathrm{X}_{2}$ & & & \\
\hline Yield (\%) & & & 33.01 & $35.02 \pm 0.35$ & $2.01 \pm 0.35$ \\
\hline $\operatorname{EGC}^{2)}(\%)$ & & & 12.56 & $13.31 \pm 0.52$ & $0.75 \pm 0.52$ \\
\hline $\mathrm{EC}(\%)$ & & & 3.78 & $3.97 \pm 0.95$ & $0.19 \pm 0.95$ \\
\hline ECGC (\%) & 6 & 0 & 22.43 & $19.11 \pm 1.33$ & $3.32 \pm 1.33$ \\
\hline ECG $(\%)$ & & & 5.39 & $4.29 \pm 0.64$ & $1.11 \pm 0.64$ \\
\hline Caffeine (\%) & & & 5.87 & $5.3 \pm 0.22$ & $0.57 \pm 0.22$ \\
\hline Total catechin (\%) & & & 40.17 & $40.68 \pm 3.09$ & $0.5 \pm 3.09$ \\
\hline
\end{tabular}

${ }^{1)} \mathrm{X}_{1}$, ratio of solvent to sample content $(\mathrm{mL} / \mathrm{g}) ; \mathrm{X}_{2}$, Extraction temperature $\left({ }^{\circ} \mathrm{C}\right)$. ${ }^{2}$ Epigallocatechin (EGC), Epicathchin (EC), Epigallocatechingallate (EGCG), Epicatechingallate (ECG).

\section{요 약}

녹차 추출물의 에탄올을 이용한 카테킨 성분의 고순도 및 고효율 추출을 위한 추출조건을 반응표면분석법을 사용 하여 최적화하였다. 고형분 수율은 에탄올 사용 비율 및 온도 조건 모두 유의적으로 영향을 받았다 $(\mathrm{p}<0.001)$. 녹차 의 카테킨 성분 함량 및 총 카테킨 함량 모두 $1 \%$ 이내의 유의성이 인정되었고 온도보다 에탄올 사용 비율 조건이 추출결과에 더 영향을 미친다. 카페인 함량은 에탄올 사용 비율에 유의적으로 영향을 받았다. 반응표면 분석 결과 카 페인을 제외한 종속변수의 $\mathrm{R}^{2}$ 값은 0.90 이상으로 $1 \%$ 이내 의 유의성이 인정되었다. 예측된 조건은 에탄올 사용 비율 이 $6 \mathrm{~mL} / \mathrm{g}$, 온도가 $0^{\circ} \mathrm{C}$ 에서 고형분 수율 $33.01 \%, \mathrm{EGC}$ $12.56 \%$, EC 3.78\%, EGCG 22.43\%, ECG 5.39\%로 총 카테킨 함량은 $40.17 \%$ 이며 카페인 함량은 $5.87 \%$ 로 예측되었다. 예측된 조건에서 실제 추출시 고형분 수율은 $35.02 \%, \mathrm{EGC}$ $13.31 \%$, EC 3.97\%, EGCG 19.11\%, ECG 4.29\%로 총 카테킨 함량은 $40.68 \%$ 이며 카페인 함량은 $5.30 \%$ 로 분석되었다. 


\section{References}

1. Khan N, Mukhtar H (2007) Tea polyphenols for health promotion. Life Sci, 81, 519-533

2. Oh MJ, Hong BH (1995) Variation of pectin, catechins and caffein contents in Korean green tea (Camellia sinensis L.) by harvesting time and processing recipe. Korean J Crop Sci, 40, 775-781

3. Lee LS, Kim SH, Park JD, Kim YB, Kim YC (2015) Physicochemical properties and antioxidant activities of loose-leaf green tea commercially available in Korea. Korean J Food Sci Technol, 47, 419-424

4. Park JH (1997) Studies on chemical composition in Korean native tea plants. $\mathrm{Ph} \mathrm{D}$ Thesis, Chonnam National University, Korea

5. Goli AH, Barzegar M, Sahari MA (2005) Antioxidant activity and total phenolic compounds of pistachio (Pistachia vera) hull extracts. Food Chem, 92, 521-525

6. Park YH, Won EK, Son DJ (2002) Effect of $\mathrm{pH}$ on the stability of green tea catechins. J Fd Hyg Safety, 17, 117-123

7. Henning SM, Fajardo-Lira C, Lee HW, Youssefian AA, Go VL, Heber D (2003) Catechin content of 18 teas and a green tea extract supplement correlates with the antioxidant capacity. Nutr Cancer, 45, 226-235

8. Wang H, Provan GJ, Helliwell K (2000) Tea flavonoids: their functions, utilisation and analysis. Trends Food Sci Technol, 11, 152-160

9. Yeo SC, Ahn CW, Lee YW, Lee TG, Park YH, Kim SB (1995) Antioxidative effect of tea extracts from green tea, oolong tea, and black tea. J Korean Soc Food Nutr, 24, 299-304

10. Song JM, Park KD, Lee KH, Byun YH, Park JH, Kim SH, Kim JH, Seong BL (2007) Biological evaluation of anti-influenza viral activity of semi-synthetic catechin dereivatives. Antiviral Res, 76, 178-185

11. Khan SM, Kour G (2007) Subacute oral toxicity of chlorpyriphos and protective effect of green tea extract. Pestic Biochem Phys, 89, 118-123

12. Miao YL, Shi LH, Lei ZL, Huang JC, Yang JW, Yang YC, Sun QY, Chen DY (2007) Effects of caffeine on in vivo and in vitro oocyte maturation in mice. Theriogenology, 68, 640-645

13. Keast RS, Riddell LJ (2007) Caffeine as flavor additive in soft-drinks. Appetite, 49, 255-259

14. Higgins GA, Grzelak ME, Pond AJ, Cohen-williams ME, Hodgson RA, Varty GB (2007) The effect of caffeine to increase reaction time in the rat during a test of attention is mediated through antagonism of adenosine A2A receptors. Behav Brain Res, 185, 32-42

15. Kim SH, Lee MH, Jeong YJ (2014) Current trends and development substitute tea and plan in the Korea green tea industry. Food Industry and Nutrition, 19, 20-25

16. Kwon TU, Park SB, Im HG, Moon IS (2002) Adsorption characteristic of catechins from green tea on activated carbone. Theories and application of chem Eng, 8, 3389-3392

17. Kim SH (2003) Chemical and physiochemical properties of Korean green tea and development of functional foods from its active components. Final Report of KFRI, GA0393-0248

18. Ministry of Food and Drug Safety (2016) Health Functional Food Code. Korea Food and Drug Administration. Korea, section $\Pi, \mathrm{p} 55$

19. Choung MG, Lee MS (2008) Optimal HPLC condition for simultaneous determination of catechins and caffeine in green tea extracts. Korean J Crop sci, 53, 224-232

20. Lu MJ, Chen C (2008) Enzymatic modification by tannase increases the antioxidant activity of green tea. Food Res Int, 41, 130-137

21. Kumamoto M, Sonda T (1998) Evaluation of the antioxidative activity of tea by an oxygen electrode method. Biosci Biotechnol Biochem, 62, 175-177

22. Pinelo M, Rubilar M, Jerez M, Sineriro J, Nunez MJ (2005) Effect of solvent, temperature, and solvent-tosolid ratio on the total phenolic content and antiradical activity of extracts from different components of grape pomace. J Agric Food Chem, 53, 2111-2117

23. Cuevas-Valenzuela J, Gonzalez-Rojas A, Wisniak J, Apelblat A, Perez-Correa JR (2014) Solubility of $(+)$-catechin in water and water- ethanol mixtures within the temperature range 277.6- 331.2 K: Fundamental data to design polyphenol extraction processes. Fluid Phase Equilibria, 382, 279-285

24. Akerlof G (1932) Dielectric constants of some organic solvent-water mixtures at various temperatures. J Am Chem Soc, 54, 4125-4139

25. Alves LA, Silvia JBA, Giulietti M (2007) Solubility of D-glucose in water and ethanol/water mixtures. J Chem Eng Data, 52, 2166-2170

26. Needhem TE (1970) The solubility of amino acids in various solvent systems. $\mathrm{Ph} \mathrm{D}$ Thesis, University of Rhode Island, Island, p 159 